\title{
The Effect of Hyperthermia in vitro on Vitality of Rabbit Preimplantation Embryos
}

\author{
A.V. MAKAREVICH ${ }^{1,3}$, L. OLEXIKOVÁ ${ }^{1,2}$, P. CHRENEK $^{1}$, E. KUBOVIČOVÁ ${ }^{1}$, \\ K. FRÉHAROVÁ ${ }^{3}$ J. PIVKO ${ }^{1}$ \\ ${ }^{1}$ Slovak Agricultural Research Centre, Nitra, ${ }^{2}$ Slovak Agricultural University, Nitra, Slovak \\ Republic and ${ }^{3}$ Research Institute of Cattle Breeding, Ltd., Rapotín, Vikýrovice, Czech Republic
}

Received September 1, 2006

Accepted October 31, 2006

On-line available November 11, 2006

\begin{abstract}
Summary
The aim of our study was to test the influence of short exposure $(6 \mathrm{~h})$ of preimplantation rabbit embryos to elevated temperatures $\left(41.5^{\circ} \mathrm{C}\right.$ or $\left.42.5{ }^{\circ} \mathrm{C}\right)$ in vitro on their developmental capacity. Fertilized eggs recovered from female oviducts at the pronuclear stage $(19 \mathrm{hpc})$ were cultured at standard temperature $\left(37.5^{\circ} \mathrm{C}\right)$ until the morula stage $(72 \mathrm{hpc})$. Afterwards, the embryos were divided into two groups, cultured for $6 \mathrm{~h}$ either at hyperthermic $\left(41.5^{\circ} \mathrm{C}\right.$ or $42.5^{\circ} \mathrm{C}$ ) or standard temperature (control $37.5^{\circ} \mathrm{C}$ ), post-incubated overnight $\left(16-20 \mathrm{~h}\right.$ ) at $37.5^{\circ} \mathrm{C}$ and then evaluated for developmental stages, apoptosis (TUNEL), proliferation (cell number), actin cytoskeleton and presence of heat-shock proteins Hsp70. It was observed that hyperthermia at $41.5{ }^{\circ} \mathrm{C}$ did not alter progression of embryos to higher preimplantation stages (expanded and hatching/hatched blastocysts), rate of apoptosis, total cell number of blastocysts and structure of actin filament compared to $37.5{ }^{\circ} \mathrm{C}$. Western-blotting revealed the presence of heat stress-induced $72 \mathrm{kDa}$ fraction of $\mathrm{Hsp} 70$ proteins in granulosa cells (exposed to $41^{\circ} \mathrm{C}$ ) and embryos (exposed to $41.5^{\circ} \mathrm{C}$ ). Following the elevation of temperature to $42.5^{\circ} \mathrm{C}$ embryo development was dramatically compromised. The embryos were arrested at the morula or early blastocyst stage, showed an increased rate of apoptosis and decreased total cell number compared to control. The structure of actin filaments in most of blastomeres was damaged and such blastomeres often contained apoptotic nuclei. In this group a presence of heat-stress-induced fraction of Hsp70 proteins had not been confirmed. This is the first report demonstrating a threshold of thermotolerance of rabbit preimplantation embryos to hyperthermic exposure in vitro. A detrimental effect of higher temperature on the embryo is probably associated with the loss of their ability to produce Hsp70 de novo, which leads to cytoskeleton alterations and enhanced apoptosis.
\end{abstract}

Key words

Rabbit $\bullet$ Embryos $\bullet$ Hyperthermia $\bullet$ Apoptosis $\bullet$ Hsp70 • Actin

\section{Introduction}

Damage induced by heat stress during preimplantation development may negatively influence the developmental program decreasing proteosynthesis and survival of embryos (Putney et al. 1988, Ealy et al. 1993). Particularly, such injury may include destruction of the cytoskeleton and subsequently cell death (apoptosis or necrosis). Ultrastructural alterations caused by heat shock may result in translocation of organelles toward the 
center of the embryonic cell (Rivera et al. 2004). The consequences of heat stress are dependent on the temperature, exposure duration and developmental stage of the embryo. In particular, disorders in development of pig embryos occurred after a short time (10-60 min) incubation at $43-45.5^{\circ} \mathrm{C}$, while at $42{ }^{\circ} \mathrm{C}$ the embryos had even a higher cell number and diameter than at control temperature (Kojima et al. 1996). In bovine, development capacity of embryos was decreased at $43{ }^{\circ} \mathrm{C}$ (Ju et al. 1999). In most species deleterious influence of heat shock is reduced during embryo development. According to Sakatani et al. (2004) development to blastocyst and proliferation were reduced, when embryos were exposed to heat stress at an early stage.

It was suggested that the elevation of thermotolerance is associated with transition from maternal to zygotic genome expression (Ju et al. 1999). This means that the embryo during development acquires one or more thermoprotective adaptation reactions. This adaptative phenomenon was observed in vivo in sheep (Dutt 1963), pigs (Tompkins et al. 1967), cattle (Putney et al. 1988) and rabbit (Wolfenson and Blum 1988) as well as in vitro in cattle (Edwards and Hansen 1997, Ealy et al. 1995). It was shown in sheep and cattle that the temperature, higher than $37{ }^{\circ} \mathrm{C}$, induces the production of a protein known as heat-shock protein 70 (Hsp 70) by embryonic cells. Heat shock proteins (Hsps) are produced among the first proteins during embryonic development and enable cells to survive and eliminate unfavorable influences protecting cellular proteins against denaturation. Therefore, Hsps are probably one of factors of resistance to thermal as well as other forms of stress. Mirkes et al. (1999) reported that Hsp 70 induces thermotolerance in mouse post-implantation embryos and the level of thermotolerance depends on the level of Hsp 70 expression itself.

One of processes involved in acquisition of resistance against heat shock may be stress-induced apoptosis (Paula-Lopes and Hansen 2002). It is proved that increased occurrence of apoptosis in cells exposed to heat stress can be reduced by Hsp 70 formation induced by moderate heat shock (Mosser et al. 1997, McMilan et al. 1998). The apoptosis frequency in embryos depends on the intensity of heat shock. Apoptotic cell percentage in bovine blastocysts was increased with the elevation of temperature. At a minimum of $41{ }^{\circ} \mathrm{C}$ the occurrence of apoptosis depends on the duration of heat shock (PaulaLopes and Hansen 2002). Despite permanently accumulating data about heat stress influence on embryos a mechanism of thermotolerance acquisition in embryos is still not clear. Moreover, the response of embryos to temperature elevation is species-specific and the critical temperature for each embryo species is different.

Currently, little data is available regarding the effects of exposure to elevated temperatures on cytoskeleton organization. Generally, more information is available on the physiological responses of the cell to heat stress, compared to those of mammalian oocytes and embryos (Ju 2005). To better understand the mechanisms of thermal injuries or tolerance, more work on cellular and molecular changes in oocytes and embryos in response to heat shock is necessary.

The aim of this study was to examine the effect of short exposure $(6 \mathrm{~h})$ to elevated temperatures $\left(41.5^{\circ} \mathrm{C}\right.$ and $42.5^{\circ} \mathrm{C}$ ) in vitro on the developmental capacity of rabbit preimplantation embryos. These temperature values and duration of exposure were chosen as a midpoint in the range of commonly used parameters published in the literature.

\section{Materials and Methods}

\section{Ethical review}

Realization of hyperthermia experiments on rabbits was approved by the ethical commission at The State Veterinary and Food Committee of the Slovak Republic under the license Č.K. Ro 2058/06-221/3a.

\section{Design of experiments}

Female New Zealand White rabbits, kept at the local farm, were treated with PMSG (Werfaser, Alvetra und WERFFT, Wien, Austria) i.m. at $20 \mathrm{IU} / \mathrm{kg}$ body weight, $72 \mathrm{~h}$ before mating. Immediately prior to mating, the females received an i.m. injection of hCG (Werfachor, Alvetra and WERFFT) at $40 \mathrm{IU} / \mathrm{kg}$ body weight. Thereafter, the females were mated with a male of proven fertility from the same breed. At 19 to $20 \mathrm{~h}$ post coitum (hpc) the pronuclear stage eggs were flushed from the oviducts of slaughtered animals with PBS (Gibco, Auckland, New Zealand). The flushed eggs were evaluated morphologically and eggs with two pronuclei, two polar bodies and compact cytoplasm were selected for the experiments. The eggs were placed into 4-well dishes (Nunc, Roskilde, Denmark), containing $600 \mu \mathrm{l}$ of k-DMEM medium (Gibco) supplemented with $10 \%$ FCS, and cultured in $5 \% \mathrm{CO}_{2}$ at $37.5^{\circ} \mathrm{C}$, up to $72 \mathrm{~h}$ post coitum (hpc). Afterwards, the embryos which reached the morula stage were selected, transferred to a drop of fresh 
culture medium, randomly divided into two groups: control (at $\left.37.5^{\circ} \mathrm{C}\right)$ and hyperthermic $\left(41.5^{\circ} \mathrm{C}\right.$ or $\left.42.5^{\circ} \mathrm{C}\right)$ group and incubated for $6 \mathrm{~h}$. Then the embryos from the hyperthermic group were transferred to a standard temperature $\left(37.5^{\circ} \mathrm{C}\right)$ and incubated overnight $(16-18 \mathrm{~h})$. Following incubation, the embryos were examined for the development (blastocyst rate) and analyzed for apoptosis (TUNEL assay), proliferation (total cell number per blastocyst), cytoskeleton (actin filaments) and presence of Hsp70 proteins (SDS-PAGE/Western-blotting). For incubation experiments, we used two $\mathrm{CO}_{2}$-incubators MCO15AC (SANYO), which were adjusted to the required temperature. All parameters of incubators were calibrated by a company's service person tightly before starting the hyperthermia experiments. Moreover, the actual temperature was regularly checked using standard thermometers, which were put inside the incubators. No deviations from adjusted temperature were recorded during 6-h incubation.

The procedure for TUNEL, actin cytoskeleton and total cell number determination

The embryos were removed from the culture medium, washed $(3 \times 5 \mathrm{~min})$ in PBS supplemented with polyvinylpyrrolidone (PBS-PVP, $4 \mathrm{mg} / \mathrm{ml}$ ), and then fixed for $5 \mathrm{~min}$ in neutrally buffered formalin $(3.7 \% \mathrm{w} / \mathrm{v}$, $\mathrm{pH} 7.2$ ) and for $10 \mathrm{~min}$ in $70 \%$ ethanol. For membrane permeabilization, the embryos were incubated for $15 \mathrm{~min}$ in $0.5 \% \mathrm{v} / \mathrm{v}$ Triton X100 in PBS. Non-specific binding was suppressed by incubation in blocking solution (1\% $\mathrm{w} / \mathrm{v}$ BSA in PBS). The embryos were processed for TUNEL using MEBSTAIN Apoptosis kit Direct (Immunotech, Marseille, France) according to the kit instruction. Briefly, fixed and permeabilized embryos were incubated in TdT end-labeling cocktail (TdT buffer, FITC-dUTP and TdT) at $37{ }^{\circ} \mathrm{C}$ for one hour. As a positive control for TUNEL, a group of fixed embryos was incubated in the presence of bovine DNAse I $\left(1 \mu \mathrm{g} / \mathrm{ml}\right.$ in PBS) for $1 \mathrm{~h}$ at $37{ }^{\circ} \mathrm{C}$ before the TdT-end labeling reaction. Thereafter the protocol was continued as above. The specificity of the TUNEL-reaction was verified by omitting the $\mathrm{TdT}$ end-labeling reagent from the protocol (negative control).

TUNEL-reaction was stopped by washing embryos three times in PBS-PVP. Then the embryos were incubated in Phalloidin-TRITC (Chemicon) diluted at 1:500 in a washing buffer for $45 \mathrm{~min}$. After incubation, the embryos were thoroughly washed in PBS-PVP, placed into a small drop on a coverslip and covered immediately with $5 \mu \mathrm{l}$ of Vectashield mounting medium containing DAPI stain (Vector Laboratories Inc., Burlingame, CA, USA). DAPI was used to counterstain all embryonic nuclei for the total cell number determination. The coverslip was mounted on a microslide and attached with nail polish. The slides were stored at $-20{ }^{\circ} \mathrm{C}$ until analysis under a Leica fluorescent microscope.

\section{Western-blotting for the detection of Hsp 70 proteins}

For the detection of Hsp 70 proteins Westernblotting of embryo lysates was used. As a control to confirm the formation of inducible form of Hsp 70, the lysates of ovarian granulosa cells, incubated at $41{ }^{\circ} \mathrm{C}$ overnight were used. The embryos (at least 25 per group) were put in SDS sample buffer with 2-mercaptoethanol (ICN Biomedicals Inc., OH, USA) and lyzed by repeated pipetting and a triple freezing-thawing procedure. Before electrophoresis, embryo lysates were heated at $95^{\circ} \mathrm{C}$ with vigorous shaking for $5 \mathrm{~min}$ and cooled to room temperature. Granulosa cell lysates were prepared as described for the embryos. Samples of embryo and cell lysates were electrophoresed in $4 \%$ (stacking gel) and $10 \%$ (resolving gel) polyacrylamide at $200 \mathrm{~V}$ constant voltages according to Laemmli (1970).

The protein fractions from the gel were transferred onto a nitrocellulose membrane Porablot NCP (Macherey-Nagel, Duren, Germany) by wet transfer in a transfer buffer $\left(25 \mathrm{mmol}^{-1} \mathrm{I}^{-1}\right.$ Tris, $192 \mathrm{mmol.}^{-1}$ glycine, $20 \%$ methanol, pH 8.3) using Mini Trans-Blot electrophoretic Transfer Cell (Bio-Rad) for one hour. Endogenous peroxidase in samples was quenched by incubation in $3 \% \mathrm{H}_{2} \mathrm{O}_{2}$ for $15 \mathrm{~min}$. Non-specific binding of antiserum was blocked by incubation in $5 \%$ BSA (Santa Cruz Biotechnology, Santa Cruz, CA, USA) in TTBS (20 mmol..$^{-1}$ Tris-base, $137 \mathrm{mmol.} \mathrm{I}^{-1} \mathrm{NaCl}, 0.1 \%$ Tween-20, pH 7.5). Blocked membranes were probed with mouse anti-HSP70 monoclonal antibody (Chemicon International Inc., Temecula, CA, USA) at 1: 500 dilution for one hour. This antibody reacts with the inducible form (Hsp 72) and constitutive form of Hsp 70 proteins. The membrane was then incubated with secondary horseradish peroxidase-conjugated goat anti-mouse IgG antibody (Upstate, Temecula, CA, USA) at 1: 1000 dilution for one hour. Positive reactions on the membrane were visualized using Visualizer $^{\mathrm{TM}}$ Western Blot Detection Kit (Upstate) and ECL Hyper-film (Amersham Life Science, Little Chalfont, UK). For negative control, the membrane was treated as described, but the primary 
Table 1. The influence of hyperthermia $(\mathrm{HT})$ in vitro on the development of rabbit preimplantation embryos.

\begin{tabular}{|c|c|c|c|c|c|c|}
\hline \multirow[t]{2}{*}{ Group } & \multirow{2}{*}{$\begin{array}{c}\text { Number of } \\
\text { embryos }\end{array}$} & \multicolumn{5}{|c|}{ Developmental stages, $\mathrm{n}(\%)$} \\
\hline & & Morula & $\mathbf{E B} \mathbf{l}+\mathbf{B l}$ & XBI & HBI & $\mathbf{X B I}+\mathbf{H B}$ \\
\hline Control $\left(37.5^{\circ} \mathrm{C}\right)$ & 142 & $24(16.9)$ & $6+44(35.2)$ & $34(23.9)$ & $34(23.9)$ & $68(47.9)$ \\
\hline$H T\left(41.5^{\circ} \mathrm{C}\right)$ & 129 & $23(17.8)$ & $6+30(27.9)$ & $35(27.1)$ & $35(27.1)$ & $70(54.3)$ \\
\hline Control $\left(37.5^{\circ} \mathrm{C}\right)^{a}$ & 54 & $4(7.4)$ & $2+8(18.5)$ & $22(40.7)$ & $18(33.3)$ & $40(74)$ \\
\hline$H T\left(42.5^{\circ} \mathrm{C}\right)^{b}$ & 52 & $4(7.7)$ & $48(92.3)$ & - & - & - \\
\hline
\end{tabular}

${ }^{a}$ vs ${ }^{b}$ - differences between groups are significant at $\mathrm{p}<0.001$ (Chi-square test) $\mathrm{EBI}-$ early $\mathrm{BI}, \mathrm{XBI}-$ expanded $\mathrm{BI}, \mathrm{HBI}-\mathrm{hatching}$ or hatched $\mathrm{BI}$.

antibody was omitted. The molecular weights of fractions were evaluated using Chemiluminescent BlueRanger (Pierce, Rockford, IL, USA) - pre-stained peroxidaselabeled protein molecular weight marker mix (17.1-207 $\mathrm{kDa})$.

\section{Statistics}

The influence of the treatment on developmental stages of embryos was evaluated by the Chi-square test. Individual multiple comparisons of the probability within stages, i.e. between groups were evaluated by the U-test. Differences between groups were estimated using oneway analysis of variance with fixed effects. The variable "TUNEL-index" was normally distributed. The hypothesis of normality was rejected for "TUNEL cells per embryo" and for "Embryo cell number". For these two variables the log-transformation of original values was used to improve the statistical properties before applying statistical tests. All calculations were performed using statistical package SPSS for Windows, Release 6.0, 1989-1993.

\section{Results}

\section{Influence of heat shock on embryo development}

Hyperthermic conditions at $41.5{ }^{\circ} \mathrm{C}$ temperature for $6 \mathrm{~h}$ did not significantly influence embryo development up to the highest preimplantation stages (Table 1). Although a higher number of expanded (XBl) and hatching/hatched ( $\mathrm{HBl}$ ) blastocysts was observed in the hyperthermic (HT) group at $41.5^{\circ} \mathrm{C}$, the differences compared with the control group were not significant. Dramatic changes in embryo development occurred following elevation of temperature to $42.5{ }^{\circ} \mathrm{C}$. In this group the embryos were arrested and did not develop up to $\mathrm{XBl}$ and $\mathrm{HBl}$ stages (Table 1).

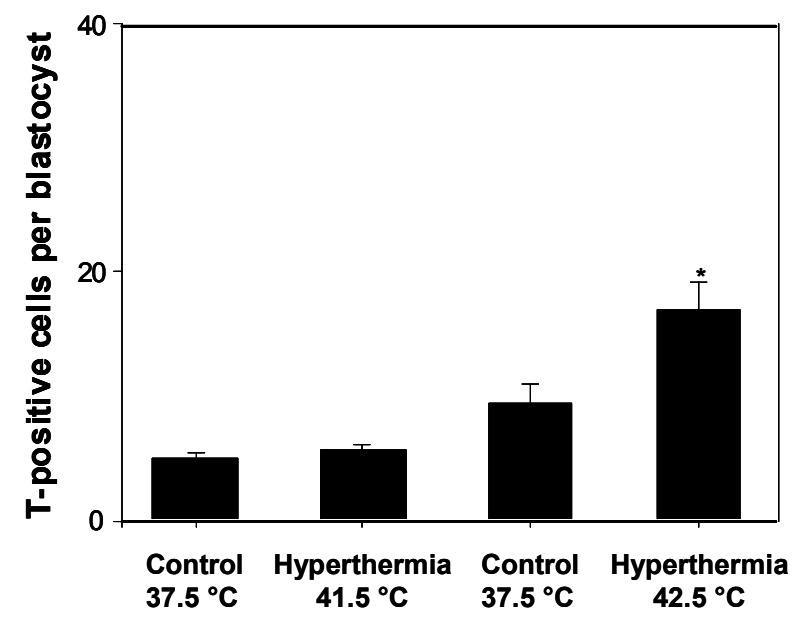

Fig. 1. Influence of hyperthermia on average number of TUNELpositive cells per blastocysts, data are mean \pm S.E.M. $*$ - significant difference compared to related control at $p<0.05$.

Influence of heat shock on apoptosis and embryo cell number

The occurrence of apoptosis was also not affected by heat shock at $41.5{ }^{\circ} \mathrm{C}$. In either group, all embryos had at least one TUNEL-positive cell. Neither average number of TUNEL-positive cells per embryo (Fig. 1) nor TUNEL-index (Fig. 2) were different between control and HT groups. Similarly, hyperthermia at $41.5{ }^{\circ} \mathrm{C}$ did not influence the cell proliferation value determined as a total cell number (Fig. 3). Following elevation of heat shock to $42.5{ }^{\circ} \mathrm{C}$, the number of $\mathrm{T}$ positive cells per embryo and apoptotic index were increased (Figs 1 and 2), while total cell number was significantly lower compared to the controls (Fig. 3).

\section{Influence of heat shock on the actin cytoskeleton}

In embryos cultured at control temperature the actin cytoskeleton was represented as sharply stained actin filaments (Fig. 4A). In a group of embryos incubated at $41.5^{\circ} \mathrm{C}$, the actin filament organization was not largely 


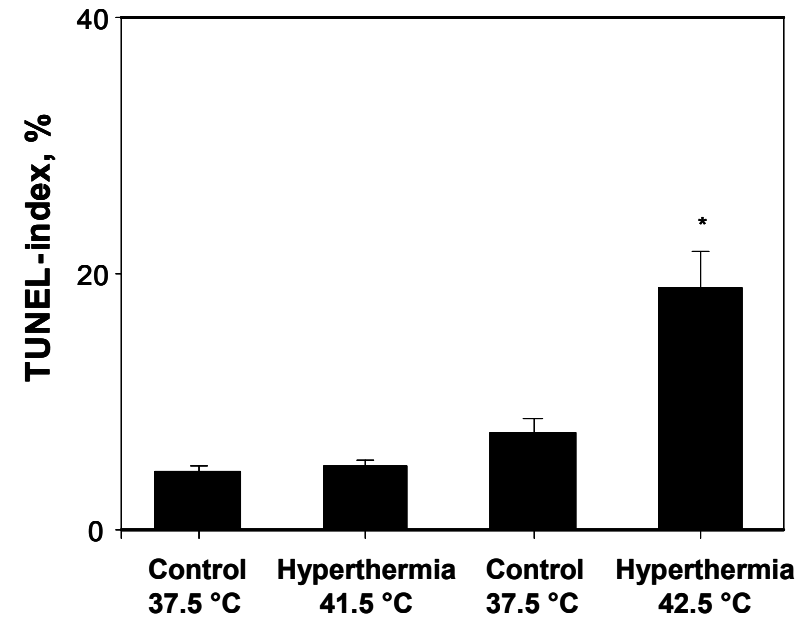

Fig. 2. Influence of hyperthermia on TUNEL-index of rabbit blastocysts. * - significant difference compared to related control at $\mathrm{p}<0.05$.

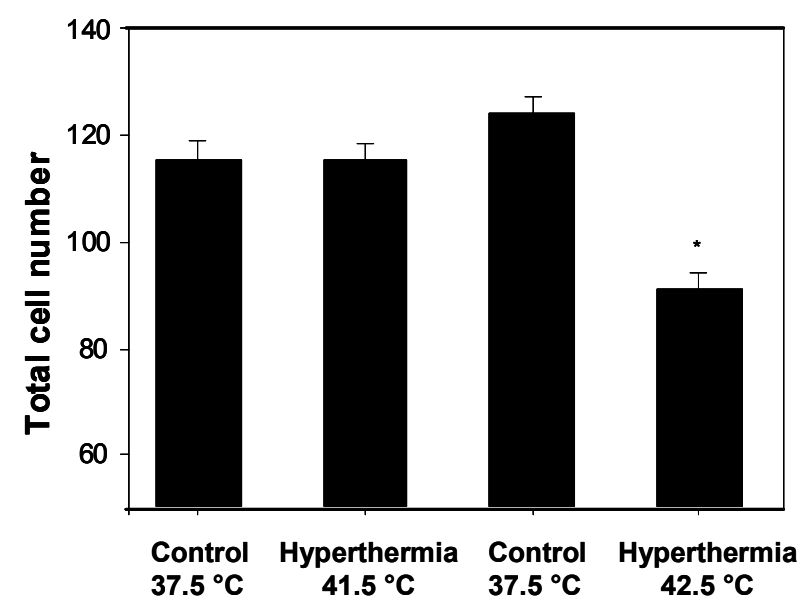

Fig. 3. Influence of hyperthermia on total cell number per rabbit blastocyst. * - significant difference compared to related control at $\mathrm{p}<0.05$.

disturbed but less distinct outlining of actin was noted (Fig. 4B). After heat shock at $42.5^{\circ} \mathrm{C}$, actin cytoskeleton had large areas lacking actin staining and visible actin was mostly aggregated in intracytoplasmic clumps (Fig. 4C). A higher number of apoptotic (TUNEL-positive) cells was observed in this group compared to embryos cultured at lower temperatures (Fig. 4C).

Influence of heat shock on the presence of Hsp 70 proteins in embryos

Using Western-blotting, the formation of heat shock-induced $72 \mathrm{kDa}$ fraction of $\mathrm{Hsp} 70$ protein by embryos incubated for $6 \mathrm{~h}$ at $41.5^{\circ} \mathrm{C}$ was confirmed (Fig. 5A.). In control samples (embryos exposed to $37.5^{\circ} \mathrm{C}$ ) the only fraction corresponding to a constitutive form of Hsp 70 was detected. Embryos exposed to $42.5^{\circ} \mathrm{C}$ did not
$\mathbf{A}$

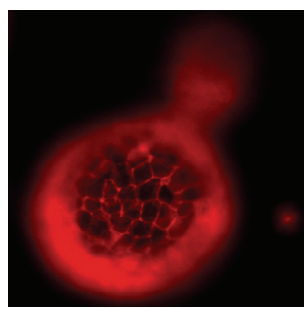

$37.5^{\circ} \mathrm{C}$

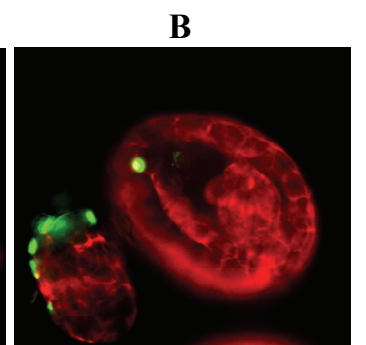

$41.5^{\circ} \mathrm{C}$
C

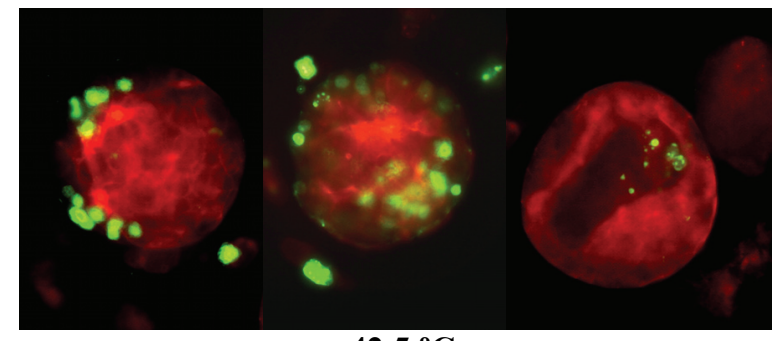

$42.5^{\circ} \mathrm{C}$

Fig. 4. Actin cytoskeleton (red fluorescence) and TUNEL-positive cells (green fluorescence) in embryos of control (A) and hyperthermic (B, C) conditions. Note sharp stained actin filaments in normally cultured embryos (A) and less distinct outlining of actin in heat-shocked at $41.5^{\circ} \mathrm{C}$ embryos (B). At $42.5^{\circ} \mathrm{C}$ actin had large areas lacking actin staining, visible actin was mostly aggregated in intracytoplasmic clumps (C). TUNELpositive cells highly occurred at $42.5^{\circ} \mathrm{C}(\mathrm{C})$ compared with lower temperatures (A, B).

reveal inducible $72 \mathrm{kDa}$ fraction of Hsp 70, which was, however, present in granulosa cell lyzates exposed to $41{ }^{\circ} \mathrm{C}$ (used as a hyperthermic control). In both control and heat stressed (at $42.5^{\circ} \mathrm{C}$ ) embryos only a constitutive $70 \mathrm{kDa}$ fraction was noted (Fig. 5B).

\section{Discussion}

In our experiments we examined the effect of two elevated temperatures during $6 \mathrm{~h}$ incubation on the developmental characteristics of rabbit embryos. Our results demonstrate that rabbit embryos at morula/early blastocyst stage, exposed to hyperthermic conditions in vitro, are resistant against the elevation of temperature up to $41.5{ }^{\circ} \mathrm{C}$, but at $42.5{ }^{\circ} \mathrm{C}$ significant alterations in embryo viability occur. Thermotolerance of embryos is generally influenced by several factors such as the duration of heat shock, temperature value, developmental stage of the embryo and their animal species. It was found in cattle (Ryan et al. 1992) that short impulses of higher temperature $\left(43{ }^{\circ} \mathrm{C}\right)$ even stimulated embryo development to hatching compared to the group without heat shock $\left(38^{\circ} \mathrm{C}\right)$. It is possible that short-term exposure (10-30 min) to the heat over $40{ }^{\circ} \mathrm{C}$ is less deleterious than chronic heat stress at lower temperatures. In our culture 
A
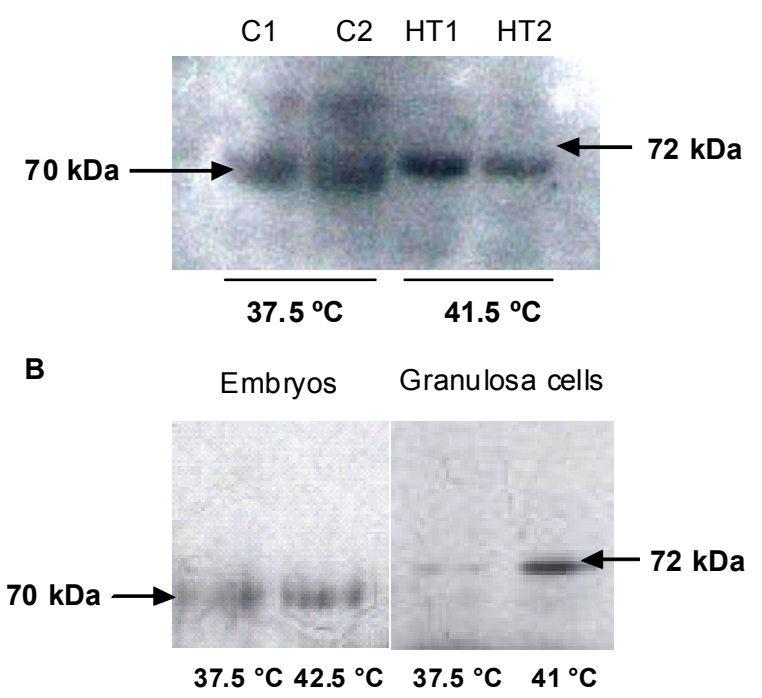

Fig. 5. Western-blotting of embryo lysates using the antibody against constitutive $(70 \mathrm{kDa})$ and inducible $(72 \mathrm{kDa})$ fractions of Hsp 70 proteins. A: Appearance of inducible $70 \mathrm{kDa}$ fraction in embryos exposed to $41.5^{\circ} \mathrm{C}$ (HT1, HT2 - are duplicates of the sample from hyperthermic group). In control samples (C1, C2 are duplicates of the same sample) only fraction corresponding to constitutive form of Hsp 70 was detected. B: Embryos exposed to $42.5^{\circ} \mathrm{C}$ did not reveal inducible $72 \mathrm{kDa} \mathrm{Hsp} 70$ fraction, whereas granulosa cell lysates exposed to $41{ }^{\circ} \mathrm{C}$ (used as a hyperthermic control) did. Only constitutive $70 \mathrm{kDa}$ fraction was noted in both control and heat-stressed embryos.

conditions the temperature $41.5^{\circ} \mathrm{C}$ did not affect embryo quality, whilst in bovine embryos at stage of less than 16 blastomeres, Jousan and Hansen (2004) already observed an increase in apoptotic cell number and reduction of cell number at $41^{\circ} \mathrm{C}$.

It is known that oocytes and early preimplantation embryos are very sensitive to heat shock (Sakatani et al. 2004) and they acquire thermoresistance during further development. For example, hyperthermia at $41{ }^{\circ} \mathrm{C}$ during $12 \mathrm{~h}$ exposure of 2-cell and 4-8 cell embryos decreased blastocyst rate, whereas heat shock influence in morula-stage embryos was not revealed (Edwards and Hansen 1997). Similar conclusions were made by Ealy et al. (1995) on bovine embryos. These facts explain the existence of thermotolerance of embryos to hyperthermia at $41.5{ }^{\circ} \mathrm{C}$ in our experimental conditions. It is supposed that the resistance of embryos against heat shock occurs as a result of Hsp 70 protein production de novo, but the precise mechanism of thermotolerance is still unclear. Thus, in mouse and bovine in vivo derived embryos a mild temperature elevation $\left(40{ }^{\circ} \mathrm{C}\right.$ for $\left.1 \mathrm{~h}\right)$ induced their thermotolerance and enhanced their ability to survive following a subsequent severe heat shock e.g. $42-43{ }^{\circ} \mathrm{C}$ for $1-2 \mathrm{~h}$
(Ealy and Hansen 1994, Paula-Lopes and Hansen 2002). However, when similar experiments were conducted using in vitro produced bovine embryos, no increased thermotolerance was observed (Ju et al. 1999).

Mirkes and Doggett (1992) stated that Hsp 72 is a potential biomarker for heat-induced embryotoxicity. Using Western-blotting they detected Hsp 72 proteins in embryos exposed to $41{ }^{\circ} \mathrm{C}, 42{ }^{\circ} \mathrm{C}(15 \mathrm{~min})$ and $43{ }^{\circ} \mathrm{C}$ (2.5 $\mathrm{min}$ ), but this protein fraction was not revealed, when embryos were cultured at $40{ }^{\circ} \mathrm{C}$ or below. They observed that, once induced, Hsp72 can be detected in embryos for 24-48 $\mathrm{h}$ after their removal from the hyperthermic conditions (Mirkes and Dogget 1992).

There are contradictory data at which temperature the Hsp70 production is induced. Particularly, in mouse Hsp70 formation was observed following shortterm heat shock at $43{ }^{\circ} \mathrm{C}$, whereas in sheep and cattle this already occurred at temperatures above $37^{\circ} \mathrm{C}$. In porcine embryos incubated at $42-45.5{ }^{\circ} \mathrm{C}$, which developed further in vivo or in vitro, neither Hsp70, nor Hsp90 protein levels were elevated (Kojima et al. 1996). The amount of Hsp proteins produced by mouse embryos, exposed to $41^{\circ} \mathrm{C}$, was positively dependent on exposure time (Mirkes et al. 1999). In our experiments on rabbit embryos the presence of $72 \mathrm{kDa}$ inducible fraction of Hsp 70 was revealed at 41.5 , but not at $37.5^{\circ} \mathrm{C}$, whereas this inducible fraction was not observed at more severe heat shock $\left(42.5{ }^{\circ} \mathrm{C}\right)$. This may be caused by a failure of protein synthesis as an irreversible consequence of severe heat shock. This is in concert with observations of Edwards and Hansen (1997) on bovine embryos, in which heat shock decreased amounts of newly synthesized Hsp70 protein.

Although it is commonly assumed that thermotolerance may be mediated by the synthesis of heat shock proteins, many reports have suggested that thermotolerance was not induced during Hsp synthesis. In mice (Edwards et al. 1995) and rat (Harris et al. 1991) it was concluded that Hsp proteins may not be sufficient themselves to confer thermotolerance in postimplantation embryos. Ju (2005) in his review stated that although Hsp proteins play a central role in cellular homeostasis and acquisition of thermotolerance, cells are able to acquire heat resistance without Hsp synthesis. A role in the development of thermotolerance may also be addressed to superoxide dismutase (SOD) (Loven et al. 1985). When Hsp synthesis in heat-treated Chinese hamster ovary cells was inhibited by cycloheximide, the SOD activity and thermotolerance was increased. 
In the present study, actin cytoskeleton in embryos exposed to $41.5{ }^{\circ} \mathrm{C}$ was not deeply affected when compared to the control group, only less expressed actin filaments were observed. On the other hand, actin structure was substantially disturbed at $42.5^{\circ} \mathrm{C}$. One of the major functions of the cytoskeleton is positioning of organelles in the cell (Kamal and Goldstein 2000). Since the cytoskeleton supports the cell membrane and maintains intracellular organelle organization (Valderrama et al. 1998), actin disorders, noted in our study, may be the main reason of embryo cleavage arrest and increased number of apoptotic cells in such embryos caused by heat shock. Effects of heat shock on the organization of the cytoskeleton are most likely dependent on the severity of heat shock and duration of treatment. Heat shock causes a rearrangement of actincontaining filaments and these changes are responsible for the movement of organelles away from the periphery, which depends on the temperature (Rivera et al. 2004). At $41{ }^{\circ} \mathrm{C}$, movement of organelles away from the periphery of the cell in bovine embryos could be blocked by either microfilament or microtubule depolymerization, while heat shock at $43{ }^{\circ} \mathrm{C}$ was sufficient to disrupt microfilament structure, as revealed using a phalloidin fluoroprobe to localize actin (Rivera et al. 2004).
In conclusion, a 6-h exposure of embryos to $41.5{ }^{\circ} \mathrm{C}$ did not impair embryo development and was associated with the formation of $72 \mathrm{kDa}$ fraction of Hsp proteins. Irreversible changes in embryos occurred at $42.5^{\circ} \mathrm{C}$, resulting in developmental arrest of preimplantation embryos, increase in apoptosis occurrence, decrease in embryo cell number and destruction of actin cytoskeleton. Impaired development of embryos subjected to heat stress could be caused, at least in part, by heat shock-induced alterations in the actin cytoskeleton and apoptotic cell death. These results demonstrate, for the first time, a threshold of thermotolerance of preimplantation rabbit embryos to short hyperthermic exposure in vitro. The detrimental effect of higher temperature on the embryo is probably associated with a loss of their ability to produce Hsp70 denovo, which leads to cytoskeleton changes and increased rate of apoptosis.

\section{Acknowledgements}

This study was supported by the grant of the Ministry of Agriculture of the Slovak Republic RUVV 06 „Protection of animal health state in certain phases of reproductive cycle following destabilization of natural systems“".

\section{References}

DUTT RH: Critical period for early embryo mortality in ewes exposed to high ambient temperature. $J$ Anim Sci 22: 713-719, 1963.

EALY AD, HANSEN PJ: Induced thermotolerance during early development of murine and bovine embryos. $J$ Cell Physiol 160: 463-468, 1994.

EALY AD, DROST M, HANSEN PJ: Developmental changes in embryonic resistance to adverse effects of maternal heat stress in cows. J Dairy Sci 76: 2899-2905, 1993.

EALY AD, HOWELL JL, MONTEROSSO VH, ARECHIGA CF, HANSEN PJ: Developmental changes in sensivity of bovine embryos to heat shock and use of antioxidants as thermoprotectants. J Anim Sci 73: 1401-1407, 1995.

EDWARDS JL, HANSEN PJ: Differential responses of bovine oocytes and preimplantation embryos to heat shock. Mol Reprod Dev 46: 138-145, 1997.

EDWARDS JL, EALY AD, HANSEN PJ: Regulation of heat shock protein 70 synthesis by heat shock in the preimplantation murine embryo. Theriogenology 44: 329-337, 1995.

HARRIS D, JUCHAU MR, MIRKES PE: Role of glutathione and Hsp 70 in the acquisition of thermotolerance in postimplantation rat embryos. Teratology 43: 229-239, 1991.

JOUSAN FD, HANSEN PJ: Insulin-like growth factor-I as a survival factor for the bovine preimplantation embryo exposed to heat shock. Biol Reprod 71: 1665-1670, 2004.

JU J-C: Cellular responses of oocytes and embryos under thermal stress: hints to molecular signalling. Anim Reprod 2: 79-90, 2005.

JU J-C, PARKS JE, YANG X: Thermotolerance of IVM-derived bovine oocytes and embryos after short-term heat shock. Mol Reprod Dev 53: 336-340, 1999. 
KAMAL A, GOLDSTEIN LSB: Connecting vesicle transport to the cytoskeleton. Curr Opinion Cell Biol 12: 503-508, 2000.

KOJIMA T, UDAGAWA K, ONISHI A, IWAHASHI H, KOMATSU Y: Effect of heat stress on development in vitro and in vivo and on synthesis of heat shock proteins in porcine embryos. Mol Reprod Dev 43: 452-457, 1996.

LAEMMLI UK: Cleavage and structure of proteins during the assembly of the head of bacteriophage T4. Nature 227: 680-685, 1970.

LOVEN DP, LEEPER DB, OBERLEY LW: Superoxide dismutase levels in Chinese hamster ovary cells and ovarian carcinoma cells after hyperthermia or exposure to cycloheximide. Cancer Res 45: 3029-3033, 1985.

MCMILLAN DR, XIAO X, SHAO L, GRAVES K, BENJAMIN IJ: Target of heat shock transcription factor 1 abolishes thermotolerance and protection against heat inducible apoptosis. J Biol Chem 273: 7523-7528, 1998.

MIRKES PE, DOGGETT B: Accumulation of heat shock protein 72 (hsp 72) in postimplantation rat embryos after exposure to various periods of hyperthermia ( 40 degrees -43 degrees $C$ ) in vitro: evidence that heat shock protein 72 is a biomarker of heat induced embryotoxicity. Teratology 46: 301-309, 1992.

MIRKES PE, CORNEL LM, WILSON KL, DILMANN WH: Heat shock protein 70 (Hsp 70) protects postimplantation murine embryos from the embryolethal effects of hyperthermia. Dev Dyn 214: 159-170, 1999.

MOSSER DD, CARON AW, BOURGET L, DENIS-LAROSE C, MASSIE B: Role of human heat shock protein hsp 70 in protection against heat induced apoptosis. Mol Cell Biol 17: 5317-5327, 1997.

PAULA-LOPES FF, HANSEN PJ: Heat shock induced apoptosis in preimplantation bovine embryos is a developmentally regulated phenomenon. Biol Reprod 66: 1169-1177, 2002.

PUTNEY DJ, DROST M, THATCHER WW: Embryonic development in superovulated dairy cattle exposed to elevated temperatures between days 1 to 7 after insemination. $J$ Reprod Biol 39: 717-728, 1988.

RIVERA RM, KELLEY KL, ERDOS GW, HANSEN PJ: Reorganization of microfilaments and microtubules by thermal stress in two-cell bovine embryos. Biol Reprod 70: 1852-1862, 2004.

RYAN DP, BLAKEWOOD EG, LYNN JW, MUNYAKAZI L: Effect of heat-stress in bovine embryo development in vitro. J Anim Sci 70: 3490-3497, 1992.

SAKATANI M, KOBAYASHI S, TAKAHASHI M: Effects of heat shock on in vitro development and intracellular oxidative state of bovine preimplantation embryos. Mol Reprod Dev 67: 77-82, 2004.

TOMPKINS EC, HEIDENREICH CJ, STOB M: Effect of after-breeding thermal stress on embryonic mortality of swine. J Anim Sci 26: 377-380, 1967.

VALDERRAMA F, BABIA T, AYALA I, KOK JW, RENAU-PIQUERAS J, EGEA G: Actin microfilaments are essential for the cytological position and morphology of the Golgi complex. Eur J Cell Biol 76: 9-17, 1998.

WOLFENSON D, BLUM O: Embryonic development, conception rate, ovarian function and structure in pregnant rabbits heat-stressed before or during implantation. Anim Reprod Sci 17: 259-270, 1988.

\section{Corresponding author}

A.V. Makarevich, Slovak Agricultural Research Centre, Hlohovska 2, Nitra, Slovak Republic. Fax: +421 376546361.

E-mail: makarevic@scpv.sk 